\title{
OCCUPATIONAL INJURIES AMONG YOUNG WORKERS IN CAR REPAIR WORKSHOPS
} IN PORT-SAID, EGYPT.

\author{
By \\ ${ }^{1}$ Abdellah RF and ${ }^{2}$ Morsy KM \\ ${ }^{1}$ Department of Community, Environment and Occupational Medicine, \\ ${ }^{2}$ Department of Emergency Medicine, Faculty of Medicine, Suez, Canal University, Ismailia, Egypt
}

\begin{abstract}
:
Introduction: The risk of having occupational injuries is higher in child workers than that in adults. Aim of work: This work was conducted to determine the prevalence of occupational injuries and to examine the factors associated with occupational injuries among young automobile repair. Materials and Methods: A cross-sectional study was conducted in Port-Said city, Egypt among young workers aged 12- 18 years old in car repair workshops. Sixty workers with at least one-year experience in their position were included using systematic random sample technique. A questionnaire was used to assess socio-demographic data, and occupational history including injury. Results: Occupational injuries were reported by $68.3 \%$ of worker during the last year. Abrasions were the chief injuries being reported and the most common body parts injured were upper limbs. A statistically significant association was found between age, years of education, smoking, duration of employment and injury occurrence among automobile repair workers $(\mathrm{p}<0.05)$. Conclusion: Majority of the child laborers in car repair workshops were facing unsafe working conditions, and encountered frequent work-related injuries and illnesses. So, it is important to develop successful policies to prevent occupational injuries and promote safer work practices for young workers.
\end{abstract}

Key words: Occupational injury, young workers, car repair workshops. 


\section{Introduction}

Child labor is one of the most severe forms of child abuse in the world. They are forced to work for living, sacrificing their childhood as well as their future for bare survival of self and family (Masum, 1999). A working child is defined as a child in the age-range of 5 to 18 who is doing labor, either paid or unpaid, and is working within or outside the family (ILO, 2011). The rates of child labor differ from one country to another, having higher rates in developing countries, especially in Africa. In Egypt, it is estimated that between 7\% to $21 \%$ of children between the ages of 6-14 are working (DHS, 2005 and UNICEF, 2011).

Early involvement of children in work leads to serious health and developmental consequences as compared with school children (UNICEF, 2011). Poor working conditions make them more susceptible than their adult colleagues to infectious diseases, injuries and other workplacerelated ailments. Many even experience amputations or loss of body parts (Noweir et al., 1993 and Rubenstein et al., 1999).

Car repair workers have higher rates of occupational health hazards compared to workers in other occupations. Work stressors are ultraviolet and thermal radiation, hot environments, noise, presence of dust, fumes, oils, grease and other chemicals, strenuous work postures, improperly designed tools and machinery and work in poor psychosocial environments (Vyas et al., 2011 ).

The occurrence of occupational injuries result from a complex interplay of multiple factors related to worker's characteristics and work stressors. Worker characteristics such as age, gender, duration of employment and literacy level have been known to influence injury occurrence (Ashi, 2003 and Bull et al., 2002). Work stressors such as elongated work schedules, overcrowded, noisy environment, improperly designed hand tools and machinery characteristics have been known to result in occupational injury occurrence (Javed et al., 2013).

Occupational injuries among young workers were more common due to lack of experience and knowledge than in adults. In addition, they begin working at an early age and often without safety training (Liu et al., 2004). Low education status, working experience, lack of health and safety training and alcoholic drink consumption were common risk factor for occupational injuries (Chau et al., 2004).

Different studies were conducted in many countries to find out the prevalence of occupational injury and identify the factors associated with it among automobile repair 
workers, but there is a lack of data to determine its magnitude among adolescent workers in Egypt. Therefore, the current study is aimed to determining it.

\section{Aim of Work}

This work was conducted to determine the prevalence of occupational injuries and to examine the factors associated with occupational injuries among young automobile repair workers in Port-said, Egypt.

\section{Materials and Methods}

A cross-sectional study was carried out in Port-Said city, Egypt among young workers aged 12- 18 years old in car repair workshops from July to September, 2013. The basic data were collected through communication with the authorities in the Occupational Department of Ministry of Manpower in Port Said to know the number and the site of different car repair workshops. In addition, a field visit was done to explore the different characteristics of the work areas.

The sample size was calculated based on the estimated prevalence of occupational injuries in automobile repair workers, which find that $63 \%$ of workers were injured (Vyas et al., 2011). Sixty workers with at least one-year experience in their position were included using systematic random sample technique.
An informed consent was taken from each participant before introducing the questionnaire; confidentiality and anonymity were maintained according to the regulations mandated by Research Ethics Committee of Faculty of Medicine Suez Canal University, in accordance with the Declaration of Helsinki. Demographic and health information data were collected using a structured interview questionnaire including the following items: Personal history, socio-demographic data, and occupational history including injury.

\section{Statistical analysis}

Data analysis was performed using SPSS 18.0 for windows. The descriptive statistics, including frequency distribution, mean, percentages, P-values of less than 0.05 , prevalence and the odd ratios of the test measures were obtained for the analysis.

\section{Results}

Socio-demographic characteristics of the workers:

This study was carried on sixty of adolescent workers in car Repair workshops in Port-Said Governorate. Their mean age \pm standard deviation $(\mathrm{SD})$ was $15.53 \pm 1.83$ years ranging from 12 to 18 years. The highest percentage of workers (51.6\%) was in the age group 16-18 years, while 
the lowest was in the age group 12 to $<14$ years. The highest percentage of workers (45.0\%) had a duration of education of 6 to $<8$ years, while the lowest $(11.6 \%)$ had a duration of education of 10 to 12 years. The mean \pm SD duration of education was $7.1 \pm$
2.06 years. As regard smoking, 20 workers was current smokers (33.3\%). The mean \pm SD of duration of smoking was $1.38 \pm$ 2.3 years. As regard number of cigarettes smoked per day, the mean $\pm \mathrm{SD}$ was $3.87 \pm$ 6.36 cigarettes/ day (Table 1 ).

Table 1: Distribution of the study group according to Socio-demographic characteristics

\begin{tabular}{|c|c|}
\hline Socio-demographic characteristics & No. \\
\hline $\begin{array}{l}\text { Age }(\mathbf{y r s}) \\
\text { Mean } \pm \text { SD } \\
\text { Range }\end{array}$ & $\begin{array}{l}15.53 \pm 1.83 \\
12-18\end{array}$ \\
\hline $\begin{array}{l}\text { Years of education (yrs) } \\
\text { Mean } \pm \text { SD } \\
\text { Range }\end{array}$ & $\begin{array}{l}7.1 \pm 2.06 \\
4-12\end{array}$ \\
\hline $\begin{array}{l}\text { Smoking habits } \\
\text { Smoker } \\
\text { Non-smoker }\end{array}$ & $\begin{array}{l}20(33.3 \%) \\
40(66.7 \%)\end{array}$ \\
\hline $\begin{array}{l}\text { Duration of smoking (yrs) } \\
\text { Mean } \pm \text { SD } \\
\text { Range }\end{array}$ & $\begin{array}{l}1.38 \pm 2.37 \\
1-12\end{array}$ \\
\hline $\begin{array}{l}\text { Number of cigarette/day } \\
\text { Mean } \pm \text { SD } \\
\text { Range }\end{array}$ & $\begin{array}{l}3.87 \pm 6.36 \\
3-20\end{array}$ \\
\hline
\end{tabular}




\section{Occupational history}

The highest percentage of workers $(53.3 \%)$ had duration of work of less than 3 years, while the lowest $(5 \%)$ had duration of work of more than 7 years ranging from 1 to 10 years. The mean \pm SD duration of work was $3.13 \pm 2.2$ years. The highest percentage of workers $(61.6 \%)$ was working for more than 8 hours/ day. As regards the use protective devices, $80 \%$ of workers did not use personal protective devices. As regard job satisfaction, $43(71.7 \%)$ were satisfied from their job (Table 2).

Table 2: Distribution of the study group according to Occupational history

\begin{tabular}{|l|l|}
\hline Occupational history & No. \\
\hline $\begin{array}{l}\text { Duration of work (yrs) } \\
\text { Mean } \pm \text { SD } \\
\text { Range }\end{array}$ & $\begin{array}{l}3.13 \pm 2.2 \\
1-10\end{array}$ \\
\hline $\begin{array}{l}\text { Working hours (h/d) } \\
\text { Range SD }\end{array}$ & $\begin{array}{l}9.27 \pm 1.61 \\
6-12\end{array}$ \\
\hline $\begin{array}{l}\text { Using of personal protective equipment } \\
\text { Yes } \\
\text { No }\end{array}$ & $\begin{array}{l}12(20 \%) \\
48(80 \%)\end{array}$ \\
\hline $\begin{array}{l}\text { Job satisfaction } \\
\text { Yes }\end{array}$ & $43(71.7 \%)$ \\
No & $28.3 \%)) 17$ \\
\hline
\end{tabular}


Characteristics of occupational injuries: Abrasions, contusions, cut, burns were

In our study, $41(68.3 \%)$ of the workers chief injuries reported as shown in table 2 . Hands and fingers were the major regions reported injuries at work in last year. of body being affected (Table3).

Table 3: Distribution of the study group according to injuries

\begin{tabular}{|l|l|}
\hline \multicolumn{1}{|c|}{\begin{tabular}{c}
\multicolumn{1}{c|}{$\begin{array}{c}\text { Injuries } \\
\text { (not mutually exclusive) }\end{array}$} \\
No= 41 (\%)
\end{tabular}} \\
\hline $\begin{array}{l}\text { Types of injury } \\
\text { Conasions }\end{array}$ & $34(82.9 \%)$ \\
Cut & $28(68.3 \%)$ \\
Burns & $23(56.1 \%)$ \\
Other & $22(53.7 \%)$ \\
\hline Site of injury & $6(14.6)$ \\
Upper limb & $35(85.4 \%)$ \\
Lower limb & $29(70.7 \%)$ \\
Others & $13(31.7 \%)$ \\
\hline Number of injuries last month & \\
1- & $24(58.5 \%)$ \\
5- & $13(31.7 \%)$ \\
10- & $4(9.76 \%)$ \\
\hline Receive treatment & $17(41.5 \%)$ \\
Yes & $24(58.5 \%)$ \\
No & \\
\hline Place of treatment & $8(47.1 \%)$ \\
Work & $6(35.3 \%)$ \\
Pharmacy & $3(17.6 \%)$ \\
\hline Emergency department &
\end{tabular}


Injuries and predisposing risk factors: employment $\leq 5$ years were statistically

Bivariate analysis show that older significant associated with occupational workers (> 15 years old), less years of injuries among young workers in car repair education ( $\leq 8$ years) and duration of workshops (Table 4$)$.

Table 4: Bivariate analysis of risk factors of occupational injuries among young workers in car repair workshops

\begin{tabular}{|c|c|c|c|c|c|c|c|}
\hline \multirow{2}{*}{ Variables } & \multicolumn{2}{|c|}{ Injured } & \multirow{2}{*}{$\mathbf{X}^{2}$} & \multirow{2}{*}{ P-value } & \multirow{2}{*}{ OR } & \multicolumn{2}{|c|}{$95 \% \mathrm{CI}$} \\
\hline & Yes (41) & NO (19) & & & & Lower & Upper \\
\hline $\begin{array}{l}\text { Age } \\
\leq 15 \\
>15 \\
\end{array}$ & $\begin{array}{l}12 \\
29 \\
\end{array}$ & \begin{tabular}{|l}
17 \\
2 \\
\end{tabular} & 18.84 & 0.00 & 0.04 & 010 & 0.24 \\
\hline $\begin{array}{l}\begin{array}{l}\text { Years of } \\
\text { education } \\
\leq 8 \\
>8\end{array} \\
\end{array}$ & $\begin{array}{l}24 \\
17\end{array}$ & $\begin{array}{l}17 \\
2\end{array}$ & 5.74 & 0.01 & 0.16 & 0.03 & 0.81 \\
\hline $\begin{array}{l}\text { Current } \\
\text { smokers } \\
\text { Yes } \\
\text { No } \\
\end{array}$ & $\begin{array}{l}17 \\
24\end{array}$ & $\begin{array}{l}3 \\
16\end{array}$ & 3.85 & 0.04 & 0.26 & 0.06 & 1.05 \\
\hline $\begin{array}{l}\begin{array}{l}\text { Duration of } \\
\text { employment }\end{array} \\
\leq 5 \\
>5 \\
\end{array}$ & $\begin{array}{l}32 \\
9 \\
\end{array}$ & $\begin{array}{l}19 \\
0 \\
\end{array}$ & 4.93 & 0.02 & - & - & - \\
\hline $\begin{array}{l}\text { Work hours/ } \\
\text { day } \\
8< \\
8>\end{array}$ & $\begin{array}{l}17 \\
24\end{array}$ & $\begin{array}{l}6 \\
13\end{array}$ & 0.537 & 0.46 & 1.53 & 0.48 & 4.84 \\
\hline $\begin{array}{l}\text { Personal } \\
\text { protective } \\
\text { devices } \\
\text { Yes } \\
\text { No }\end{array}$ & $\begin{array}{l}10 \\
31\end{array}$ & $\begin{array}{l}2 \\
17\end{array}$ & 1.56 & 0.21 & 0.36 & 0.07 & 1.86 \\
\hline $\begin{array}{l}\text { Job satisfaction } \\
\text { Yes } \\
\text { No }\end{array}$ & $\begin{array}{l}28 \\
13\end{array}$ & $\begin{array}{l}15 \\
4\end{array}$ & 0.726 & 0.39 & 0.57 & 0.15 & 2.07 \\
\hline
\end{tabular}




\section{Discussion}

The potential for exposure to injuries is high, especially in the absence of strict control and regulatory measures in workplaces. Car repair workers are exposed to varied work hazards as presence of dust, hard work, improper work posture, long working hours and load lifting which increase the risk of occupational injuries. This work was carried out to determine the prevalence and patterns of injuries among adolescent workers.

In our study $68.3 \%$ of car repair workers reported injuries. This high prevalence results from poor work conditions and limited control measures. These findings coincide with Vyas et al. (2011) who reported that $63 \%$ of the workers employed as automobile garage reported injuries at work in last year. In Pakistan, the prevalence of injuries among young workers ranging from $38 \%$ to $78.4 \%$ (Khan et al., 2007 and Javed et al., 2013). This variation result from status of work force in each country, and of occupational health services.

Workers reported higher prevalence of injuries to upper extremities (Table 3). Jones and Kumar (2004) and Aggazzotti et al. (2006) also reported higher prevalence of injuries in upper extremities in saw mill industry and young Italian workers respectively. We observed a high rate abrasions, contusions, cut and burns. The results of our study agree with those of another similar study, where the data indicated that contusions (29.4\%) and cuts (22.4\%) were the most common injury types among a sample of construction workers (Abbas, 2013).

Older workers reported higher risk of injuries, but longer work experience appear to be protective (Table 4). Older workers might have more work experience, but on the other hand, it was also possible that because of their seniority, they were less exposed to the occupational hazards in the workplace. The relationship between education and occupational injuries is less consistent. A study in 2000 reported that workers with lower educational level had higher risk for injury (Xiang et al., 2000). In the current study, workers with $>8$ years education or above were at a statistically significant lower risk for injury than others (Table 4). They have more knowledge and better attitude on occupational health and safety compared to those with lower education levels (Yu et al., 2012).

According to the present study results, the great majority of adolescents in the exposed group were not using protective devices as aprons or gloves, they said "when we use them, we cannot move freely during painting process, and they do 
not help too much for our health". These findings coincide with Khaleel (2002) who demonstrated that most of the workers who were working in car-painting workshops did not use personal protective equipment during painting process.

In our study, $61.7 \%$ of workers had worked for long hours ( $<8$ hours/ day). These findings coincide with Habil and Abdelhakim (2011) who reported that 70\% worked more than 6 hours per day were at a higher risk in comparison to others who worked for shorter durations. Workers who worked for long hours might have developed fatigue and stress, which increased their risk to injury (Dembe et al., 2004).

The present study revealed that smoking among workers was $33.3 \%$ (Table 1). A similar observation was found in a study conducted in Lebanon, which revealed that the prevalence of smoking among working children was $24.7 \%$. The authors have explained that work provides children with a sense of independence and an opportunity to spend long hours outside home. This might expose them to undesirable role models and to adverse habits such as smoking, drinking, drug abuse, and endanger their ability to distinguish right from wrong (Nuwayhid et al., 2005). Our study did not find association of smoking with injury occurrence in car repair workers.

\section{Conclusion}

Based on the results of our study, we conclude that the work environment in car repair workshops lacks basic safety standard criteria such as proper ventilation, and personal protective equipment. These results therefore highlight a situation of considerable concern for the health and safety of working children. The real challenge remains a societal commitment to protect children, control child labor, and provide children with proper education and technical training.

\section{References:}

1. Abbas R, Zalat M and Ghareeb N (2013): NonFatal Occupational Injuries and Safety Climate: A Cross-Sectional Study of Construction Building Workers in Mit-Ghamr City, Dakahlia Governorate, Egypt. Journal of Safety Science and Technology; 3: 69-79.

2. Aggazzotti G, Righi E, Patorno E, Fantuzzi G, et al (2006): Work-related injuries in young workers: an Italian multi-centric epidemiological survey. Ann 1st Super Sanita; 42: 69-75.

3. Ashi B (2003): Relationships of job and some individual characteristics to occupational injuries in employed people. A community-based study. Occup Health; 45:382-391.

4. Bull N, Riise T and Moen B (2002): Workrelated injuries and occupational health and safety factors in small enterprises-Prospective study. Occup Med; 52:70-74.

5. Chau N, Mur J, Benamghar L, Siegfried C, et al (2004): Relationships between some individual characteristics and occupational accidents in the construction industry. Am J Ind Med; 45(1):8492. 
6. Dembe A, Bianca B and Rachel A (2004): Predictor of injury and illness, National survey findings. J Occup Environ Hyg; 1: 542-5.

7. Egypt Demographic and Health Survey (DHS) (2005): (www.dhsprogram.com/pubs/pdf/ FR176/FR176.pdf)

8. Egypt Program Profile (2011): Child Protection. UNICEF, Unit for children (www.unicef.org/ egypt/Child_Protection.pdf)

9. Habil I and Abdelhakim S (2011): Sociodemographic characteristics and occupational health exposures among a group of child laborers in Egypt. The Egyptian Journal of Community Medicine; 29: 4-11.

10. International Labor office (ILO) (2011): Children in hazardous work: What we know, what we need to do. International Program on the Elimination of Child Labor; 3-5.

11. Javed S, Shah N and Memon M (2013): Occupational hazards, illness and injuries faced by child laborers. J Pak Med Assoc; 63(1):13942 .

12. Jones T and Kumar S (2004): Occupational injuries and illnesses in the sawmill industry of Alberta. Int J Ind Ergon; 33: 415-27.

13. Khaleel A (2002): Solvent Exposure, Related Work Practice and Self- Reported Health Problems Among Car Painters in Workshops at Hebron City-Palestine. A Master Degree program. Institute of General Practice and Community Medicine, Faculty of Medicine, University of Oslo- Norway.

14. Khan H, Hameed A and Afridi A (2007): Study on child labour in automobile workshops of
Peshawar, Pakistan. Eastern Mediterranean Health Journal; 13 (6): 1497- 1502.

15. Liu XR, Yang JG, Jiang WZ, et al (2004): Relationship Occupational injuries with social and economic factors. Zhonghua Lao Dong Wei Sheng Zhi Ye Bing Za Zhi; 22(2):86-89.

16. Masum M (1999): A Model for Integrated Human Resources Development for the Working Children, Bangladesh. Underprivileged Children's Educational Programs (UCEP), UNICEF.

17. Noweir MH, Oman HA, Abbas FI, AbouTaleb AM, et al (1993): Child labor in Egypt. I. Occupational and socio-economic aspects. J Egypt Public Health Assoc; 68(3-4):405-42.

18. Nuwayhid I, Usta J, Makarem M, Khudr A, et al (2005): Health of children working in small urban industrial shops. Occup. Environ. Med; 62: 86-94.

19. Rubenstein H, Sternbach M and Pollack S (1999): Protecting the health and safety of working teenagers. Am Fam Physician; 60(2):575-80, 587-8.

20. Vyas H, Das S and Mehta S (2011): Occupational injuries in automobile repair workers. Ind Health; 49(5):642-51.

21. Xiang H., Wang $\mathrm{Z}$ and Stallones L (2000): Agricultural work-related injuries among farmers in Hubei, People's Republic of China. American Journal of Public Health; 90: 1269-1276.

22. Yu W, Yu IT, Li Z, Wang X, et al (2012): Workrelated injuries and musculoskeletal disorders among factory workers in a major city of China. Accident Analysis and Prevention; 48: 457- 463. 